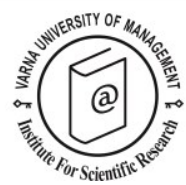

Unravelling the complexity of destination image formation:

\title{
A conceptual framework
}

\author{
Elitza lordanova ${ }^{1 *}$
}

Received: 12/09/2014 Accepted: 11/03/2015

\begin{abstract}
1 Senior Lecturer in Tourism and Aviation, Buckinghamshire New University, School Management and Professional Studies, High Wycombe Campus, Queen Alexandra Road, High Wycombe, HP11 2JZ, UK; tel: +44 (0) 1494522 141; e-mail: Elitza.Iordanova@bucks.ac.uk

* Corresponding author
\end{abstract}

\begin{abstract}
In an industry that sells experiences rather than tangible products, tourism destination image (TDI) is an important strategic marketing tool through which destinations compete with each other, strengthen their positioning on the market and attract potential visitors. TDI was an active area of researchers' investigation; however, in recent times it seems to have received less attention leaving a significant amount of unaddressed issues. The strength of this work comes essentially from the conceptual clarity it endeavours to provide by proposing a conceptual framework, which explicitly displays the multi-staged process of TDI formation and a set of image determinants based on previous empirical TDI research or included in other models of TDI formation, and also highlights under-researched areas that still require researchers' attention.
\end{abstract}

(C) 2015 Varna University of Management. All rights reserved

Keywords: destination image, destination image elements, destination image formation, destination image conceptualization, destination image determinants, destination marketing

Citation: lordanova, E. (2015) Unravelling the complexity of destination image formation: A conceptual framework. European Journal of Tourism Research 11, pp. 35-56

\section{Introduction}

Positioning a destination on the already overcrowded tourism market could prove to be a challenging activity for any destination. The intangible and inseparable nature of the tourism product further complicates the matter as destinations must be personally visited to be experienced. Consumers have to mainly envisage these experiences around the positive emotions a destination evokes in their minds (Coshall, 2000; Leisen, 2001). The use of visuality, therefore, becomes a strategic marketing tool used to differentiate destinations from competitors and positively position them in the minds of potential visitors (Gnoth et al., 2007; Kozak and Baloglu, 2011) who are believed to base their buying decisions on the mental images they have of places (Chang et al., 2015; Chen and Tsai, 2007, Cronch, 2011; Ivanov et al., 2010; Leisen, 2001; Gallarza et al., 2002; Stepchenkova and Eales, 2011, Suarez, 2011). Still, despite the significant amount of work done so far on TDI and its wellrecognized importance for destinations' 
differentiation and positioning (Ivanov et al., 2010; Kozak and Baloglu, 2011), there is still no unified definition or theoretical framework for it (Rodrigues et al., 2011; Stepchenkova and Mills, 2010; Tasci et al., 2007) mainly because of its "complex, multiple, relativistic and dynamic nature" (Gallarza et al., 2002:56) and understanding its formation still remains a challenge (Pike and Page, 2014).

This paper endeavours to provide a conceptual clarity in regard to destination image and its formation process by proposing and visualizing a conceptual framework, which explicitly i) displays the multi-staged process of TDI formation, ii) highlights the impact a set of image determinants exert over the different stages of its formation, and iii) shows underresearched areas related to destination image that still require researchers' attention and further discussions. The methodology employed in this conceptual paper is content analysis of existing tourism studies on the complexity of destination image formation and development.

This paper, firstly, juxtaposes various definitions of TDI in an attempt to shed light on the entanglement of this phenomenon since here have been numerous attempts to define it, but providing a precise definition still remains a thought-provoking task that was firstly recognized as such by Mazanec and Schweiger (1981). In addition, the issue of using perceptions, impressions, attitudes and image synonymously to describe TDI in past studies is critically approached in this paper and it is argued that this practice is one of the sources leading to perplexity among tourism researchers. The paper secondly addresses the "complex, multiple, relativistic and dynamic" (Gallarza et al., 2002:56) nature of TDI and compares various schools of thoughts on what constitutes TDI and the interlaced relationships between its constituent parts. Thirdly, the TDI formation process and its determinants, as another aspect of TDI still debated in the existing literature, are also discussed in depth in the paper (Beerli and Martin, 2004; Baloglu and McCleary, 1999).

Notwithstanding the variety of TDI formation models in the literature (e.g. Gunn 1972;
Fakeye and Crompton, 1991; Gartner, 1993; Baloglu and McCleary, 1997; Beerli and Martin, 2004; Tasci and Gartner, 2007), these models appear as partial to some extent, since they discuss either the dynamic nature of the image formation process or see TDI as a static construct that is formed under the influence of a fusion of information sources, travellers' socio-demographic and psychological characteristics. The paper then concludes with the development and visualization of a conceptual framework of destination image formation highlighting its multi-staged and complex nature and explicitly shows underresearched areas of destination image, which could prove beneficial for further studies on this important topic.

\section{Literature Review}

Image is presented as a vital and influential factor in a variety of conceptual frameworks that elucidates the travellers' decision making process (e.g. Lee et al., 2005; Molina and Esteban, 2006; Yüksel and Akgül, 2007; Ramkissoon et al. 2011) and is recognized to be what attracts people to a destination (e.g. Kim and Perdue, 2011; Lee et al., 2005, Nicoletta and Servidio, 2012). Despite its wellrecognized significance, there is still a level of ambiguity as to how to define, conceptualize and operationalize this complex phenomenon and the sections below critically review the existing body of literature on destination image definitions, its conceptualization and operationalization.

\section{Defining Image and Destination Image}

The concept of image has been analysed from a variety of perspectives, where "different aspects are covered by different disciplines" (Rodrigues et al., 2011:105). In philosophy where the roots of the interest in the process of image formation could be traced back to the Greek philosophers Plato and Aristotle, image is a reflection of the relationship between reality and individuals' perceptions of it (Rodrigues et al., 2011).

The existence and nature of the relationship between objects and their images in people's minds has been also studied from a psychological perspective where mental imagery is generally delineated as: 
quasi-perceptual experience...

experience that subjectively resembles perceptual experience, but which occurs in the absence of the relevant perceptual stimuli. (Thomas, 2009: 457).

Visual mental imagery is an ordinary, everyday experience enabled through individuals' skills to evoke past experience, or to visualize possible situations by forming mental images. The main difference between image and perception, therefore, is in the fact that while images can take place in the absence of an object, perceptions cannot (Thomas, 2009).

Geographers, on the other hand, see place images in a more holistic way as impressions, knowledge, emotions, values and beliefs of a place, whereas marketers relate image to consumer behaviour and decision making process (Jenkins, 1999).

In the field of tourism, the term "image", despite its wide application in the literature and practice, is still lacking theoretical and conceptual structure (Fakeye and Crompton, 1991; Kim and Richardson, 2003; Rodrigues et al., 2011, Teodorescu et al., 2014). There is a considerable variety of TDI definitions in the tourism literature (see Table 1 below) - some of them are complementary to each other, while others are fully contradictory, which could indicate that there is either a substantial level of uncertainty as to how to define it, or that DI is a "multidimensional and complex" (Gallarza et al., 2002: 56) concept that can be explained by all these various definitions. Moreover, definitions of TDI in tourism studies are often missing or fairly blurred, if mentioned at all (Echtner and Ritchie, 1991) and only define "a particular aspect of destination image" (Tasci et al., 2007: 199) which is illustrated in Table 1.

Ko and Park (2000) recognized three major research streams in defining TDI. Some researchers emphasize its composite structure and suggest that it is "the sum of beliefs, ideas and impressions that a person has of a destination" (e.g. Crompton, 1979:18). Others use cognitive and affective elements to portray the concept of TDI (e.g. Mazursky and Jakoby, 1986) or see it as an overall impression of a place, product or experience (e.g. Milman and Pizam, 1995; Reynolds, 1965).

Nevertheless, there are three areas in existing definitions that appear as problematic. Firstly, the majority of researchers define image as a static concept (e.g. Hunt, 1975; Bigne et al., 2001), while just a few studies embrace its dynamic structure (i.e. "over time") (e.g. BongKoo et al., 2014; Campo-Martınez et al., 2010; Choi et al., 2007; Kim and Richardson, 2003; Kim and Morrison, 2005; Smith et al., 2015; Yüksel and Akgül, 2007, Yuan et al., 2014). Secondly, some of the definitions express individual's image of a place (e.g. Coshall, 2000) whereas others deal with the stereotyped image shared by a large group of individuals (e.g. Hall, 2006). There are also definitions that do not specify which point of view is represented - the one of the general public or of the individuals (e.g. Gartner, 1989). Thirdly, in many studies impressions and perceptions of a place are used interchangeably (e.g. Tapachai and Waryszak, 2000) or are complementary to each other (e.g. Baloglu and McCleary, 1999; Echtner and Ritchie, 1991). Moreover, perceptions, impressions and attitudes are used synonymously and/or simultaneously in a considerable amount of TDI studies. For example, Bigne et al., (2001:716) argue that TDI "consists of all that the destination evokes in the individual; any idea, belief, feeling or attitude that tourists associate with the place", which calls for clarification on these diverse concepts.

Hume (an $18^{\text {th }}$ century philosopher) posits that impressions and ideas are derivatives of perceptions and differ from each other based on:

...the degree of betwixt these consists in the degrees of force and liveliness, with which they strike upon the mind, and make their way into our thought or consciousness. Those perceptions, which enter with most force and violence, we may name impressions...by ideas I mean the faint images of these in thinking and reasoning. Hume (2010:19) 
Table 1. Selected definitions of destination image

\begin{tabular}{|c|c|c|}
\hline Author/s & Year & Definition \\
\hline Oxenfeldt & 1974 & $\begin{array}{l}\text { Store image is a complex of attributes that consumers feel about the store it is more } \\
\text { than a simple sum of objective individual attributes since parts of attributes interact in } \\
\text { consumers' minds }\end{array}$ \\
\hline Hunt & 1975 & Perceptions held by potential visitors about an area \\
\hline $\begin{array}{l}\text { Lawson and Baud- } \\
\text { Bovy }\end{array}$ & 1977 & $\begin{array}{l}\text { An expression of knowledge, impressions, prejudices, imaginations and emotional } \\
\text { thoughts and individual has of a specific place }\end{array}$ \\
\hline Crompton & 1977 & Organised representations of a destination in a cognitive system \\
\hline Crompton & 1979 & Sum of beliefs, ideas, and impressions that a person has of a destination \\
\hline Assael & 1984 & $\begin{array}{l}\text { Total perception of the destination that is formed by processing information from } \\
\text { various sources over time }\end{array}$ \\
\hline Dichter & 1985 & $\begin{array}{l}\text { The concept of image can be applied to a political candidate, a product, and a country. } \\
\text { It describes not individual traits or qualities but the total impression and entity makes } \\
\text { on the minds of others }\end{array}$ \\
\hline Reynolds & 1985 & $\begin{array}{l}\text { An image is the mental construct developed by the consumer on the basis of a few } \\
\text { selected impressions among the flood of total impressions. It comes into being through } \\
\text { a creative process in which selected impressions are elaborated, embellished and } \\
\text { ordered }\end{array}$ \\
\hline Tourism Canada & 1986-1989 & How a country is perceived relative to others \\
\hline Phelps & 1986 & Perceptions or impressions of a place \\
\hline Garnter and Hunt & 1987 & Impressions that person holds about a state in which they do not reside \\
\hline Fridgen & 1987 & Mental representation of an object or place which is not physically before the observer \\
\hline Moutinho & 1987 & $\begin{array}{l}\text { An individual's attitude toward the destination attributes based on their knowledge and } \\
\text { feelings }\end{array}$ \\
\hline $\begin{array}{l}\text { Mazursky and } \\
\text { Jacoby }\end{array}$ & 1986 & $\begin{array}{l}\text { Store Image is: (1) an idiosyncratic cognition configuration and/or effect (or a set of } \\
\text { cognitions and/or effects), (2) which is (are) inferred, (3) either from a set of ongoing } \\
\text { perceptions and/or memory inputs attaching to a phenomena (i.e. either an object or } \\
\text { event such as a store, a product, a 'sale' etc.), and (4) which represent(s) what that } \\
\text { phenomenon signifies to an individual. }\end{array}$ \\
\hline $\begin{array}{l}\text { Richardson and } \\
\text { Crompton }\end{array}$ & 1988 & Perceptions of vacation attributes \\
\hline Gartner & 1989 & A complex combination of various products and associated attributes \\
\hline Calantone et al. & 1989 & Perceptions of potential tourist destinations \\
\hline Embacher and Buttle & 1989 & $\begin{array}{l}\text { Ideas or conceptions held individually or collectively of the destination under } \\
\text { investigation }\end{array}$ \\
\hline Chon & 1990 & $\begin{array}{l}\text { Result of the interaction of a person's beliefs, ideas, feelings, expectations and } \\
\text { impressions about a destination }\end{array}$ \\
\hline Echtner and Ritchie & 1991 & $\begin{array}{l}\text { The perceptions of individual destination attributes and the holistic impression made } \\
\text { by the destination }\end{array}$ \\
\hline $\begin{array}{l}\text { Fakeye and } \\
\text { Crompton }\end{array}$ & 1991 & $\begin{array}{l}\text { Image is the mental construct developed by a potential tourist on the basis of a few } \\
\text { selected impressions among the flood of total impressions }\end{array}$ \\
\hline Dagostar and Isotalo & 1992 & Overall impression or attitude that an individual acquires of a place \\
\hline Kotler et al., & 1994 & $\begin{array}{l}\text { The image of a place is the sum of beliefs, ideas, and impressions that a person holds } \\
\text { of it }\end{array}$ \\
\hline Milman and Pizam & 1995 & $\begin{array}{l}\text { Visual or mental impression of a place, a product, or an experience held by the } \\
\text { general public }\end{array}$ \\
\hline Berman and Evans & 1995 & $\begin{array}{l}\text { Store image consists of functional and emotional attributes, these are organised in the } \\
\text { perceptual structures of purchasers }\end{array}$ \\
\hline Parenteau ${ }^{1}$ & 1995 & $\begin{array}{l}\text { Is a favourable or unfavourable prejudice that the audience and distributors have of } \\
\text { the product or destination }\end{array}$ \\
\hline Gartner & 1996 & $\begin{array}{l}\text { Destination images are developed by three hierarchically interrelated components: } \\
\text { cognitive, affective, and conative }\end{array}$ \\
\hline $\begin{array}{l}\text { MacKay and } \\
\text { Fesenmaier }\end{array}$ & 1997 & $\begin{array}{l}\text { A composite of various products (attractions) and attributes woven into a total } \\
\text { impression }\end{array}$ \\
\hline
\end{tabular}




\begin{tabular}{|c|c|c|}
\hline Pritchard & 1998 & An visual or mental impression of a specific place \\
\hline $\begin{array}{l}\text { Baloglu and } \\
\text { McCleary }\end{array}$ & 1999 & $\begin{array}{l}\text { An individual's mental representation of knowledge, feelings, and global impressions } \\
\text { about a destination }\end{array}$ \\
\hline Coshall & 2000 & The individual's perceptions of the characteristics of destinations \\
\hline Murphy et al., & 2000 & $\begin{array}{l}\text { A sum of associations and pieces of information connected to a destination, which } \\
\text { would include multiple components of the destination and personal perception }\end{array}$ \\
\hline $\begin{array}{l}\text { Tapachai and } \\
\text { Waryszak }\end{array}$ & 2000 & $\begin{array}{l}\text { Perceptions or impressions of a destination held by tourists with respect to the } \\
\text { expected benefit or consumption values }\end{array}$ \\
\hline Bigne et al. & 2001 & $\begin{array}{l}\text { The subjective interpretation of reality made by the tourist Tourism destination image } \\
\text { consists of all that the destination evokes in the individual; any idea, belief, feeling or } \\
\text { attitude that tourists associate with the place }\end{array}$ \\
\hline Kim and Richardson & 2003 & $\begin{array}{l}\text { Totality of impressions, beliefs, ideas, expectations, and feelings accumulated } \\
\text { towards a place over time }\end{array}$ \\
\hline Choi et al. & 2007 & $\begin{array}{l}\text { Compilation of beliefs and impressions based on information processing from a } \\
\text { variety of sources over time, resulting in an internal mental construct representing } \\
\text { attributes of and benefits sought in a destination. }\end{array}$ \\
\hline Chen and Tsai & 2007 & The visitor's subjective perception of the destination reality. \\
\hline Tasci et al., & 2007 & $\begin{array}{l}\text { destination image is an interactive system of thoughts, opinions, feelings, } \\
\text { visualizations, and intentions toward a destination }\end{array}$ \\
\hline Chin and Qu & 2008 & $\begin{array}{l}\text { Individual's mental representation of the knowledge, feelings and overall perception of } \\
\text { a particular destination. }\end{array}$ \\
\hline $\begin{array}{l}\text { Donaldson and } \\
\text { Ferreira }\end{array}$ & 2009 & $\begin{array}{l}\text { A combination of the consumer's reasoned and emotional interpretations of a } \\
\text { destination }\end{array}$ \\
\hline Huang, Li and Cai & 2010 & $\begin{array}{l}\text { A mental structure that integrates the elements, impressions, and values people } \\
\text { project onto a specific place. }\end{array}$ \\
\hline
\end{tabular}

Source: Adapted from Gallarza, Saura and García (2002: 60), Tasci, et al. (2007: 202-203) and Martin and Bosque (2008: 264)

Note: ${ }^{1}$ Cited in Gallarza et. al. (2002)

Under the category of impressions, Hume includes "sensations, passions and emotions" (Hume, 2010:19) as they get formed in our "souls". Golledge and Stimson (1987: 12), in a similar vein, argue that "information signals are filtered through perception and then further filtered through the cognitive representation given to these in relation to previous cognitive structure in the brain".

Fridgen (1987:102), on the other hand, in his definition of image as "a mental representation of an object, person, place or event which is not physically before the observer" also points out the distinction between image and perception - environmental stimuli are required for perceptions to take place, whereas this is not a prerequisite for an image to exist (Fridgen, 1987; Thomas, 2009). Moreover, image does not necessarily include perceptions. Therefore, the use of perceptions in understanding TDI is theoretically incorrect for studies where the participants have not experienced the destination (Tasci et al., 2007).
Attention should also be paid to the use of the term "attitude" in definitions of TDI. There is an agreement in the literature that "person's attitude represents ... evaluation of the entity in question" (Ajzen and Fishbein, 1977:889), which can be positive or negative (Zimbardo et al., 1999), and is subjective because it reflects how an individual sees an object and not necessarily how the object is in reality (Olson and Maio, 2004).

The following figure shows how attitudes, perceptions, impressions, ideas and images differ, but still influence each other. Perceptions, on the one hand, are formed in the occurrence of environmental stimuli (e.g. information sources, experience) and represent a necessity for attitudes to be formed, while at the same time perceptions are not a precondition for an image to exist. Perceptions, on the other hand, form impressions and ideas, wherein the former include sensations, passions and emotions individuals feel about objects and the latter is a "faint reproduction" of 
Unravelling the complexity of destination image formation: A conceptual framework.
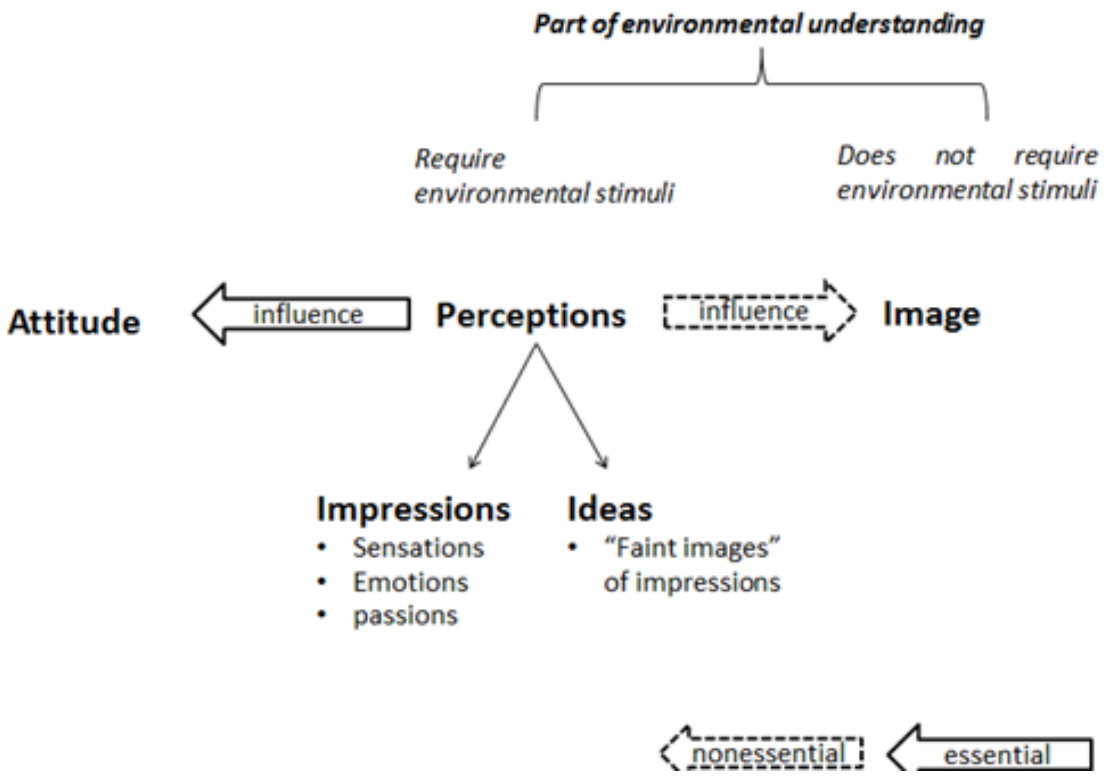

Figure 1. Differences between attitudes, perceptions, image, impressions and ideas.

them. Impressions and ideas as derivatives of perceptions also require environmental stimuli to get formed which contrasts with the concept of image where no environmental stimuli are needed.

Thus, what emerged as a source of misunderstanding with TDI definitions has its roots in the interchangeable use of attitudes, perceptions, ideas and impressions to define it. Throughout the course of this critical evaluation of TDI definitions, it was revealed that these related, but still different concepts cannot be used synonymously in order to define TDI as they represent different stages in the process of its formation. This conclusion informs a new definition of TDI presented and discussed later in the paper. The existing schools of thought on the structure of TDI are critically approached in the section that follows, as its conceptualization appears to be another profoundly debated issue in the existing literature.

Conceptualizing Image and Destination Image Boulding (1956) in his work "The Image: Knowledge in Life and Society" enters into a dialogue with himself and proposes a theory of human behaviour from a psychological perspective based on perceptions of the world.
He argues that our knowledge of the world is our image of the world. Knowledge has an implication of validity and truth and hence what we believe is true is subjective and based on our own knowledge. Consequently, our actions depend on the image we have of the world and occur as a result of past experiences. He also postulates that people's subjective knowledge consists not only of images of "fact", but also images of "value" and was among the first who recognized the existence of cognitive (knowledge) and affective dimensions (emotions) of images. Another principal theory of image formation proposed by Kelman (1965) describes images as a connection of different impressions of an object that produce a unified whole. Apart from cognitive elements, images possess an affective evaluation or an attitude towards an object.

The construct of TDI is addressed in the literature from two different angles - structured and unstructured (Lai and $\mathrm{Li}, 2012$ ). Some scholars recognise an internal, even though sometimes loose structure (e.g. Baloglu and McCleary, 1999; Echtner and Ritchie, 1991), whereas others (e.g. Crompton, 1979) support the idea that there is no recognised structure in 
TDI and it should be approached as one inseparable whole.

In tourism studies, image is sometimes considered as a multidimensional construct of two main dimensions affective and cognitive (Hosany et al., 2006, Qu et al., 2011). People's beliefs and/or knowledge of destination attributes are linked to cognitive image components (e.g. Baloglu, 1999; Gartner, 1993; Richards and Wilson, 2004) which are “...awareness, knowledge or beliefs, which may or may not have been derived from a previous visit" (Pike and Ryan, 2004:334). Tasci et al., (2007), on the other hand, broadened the definition of the cognitive dimension of TDI to a mental response that involves not only beliefs/knowledge, but also memories, evaluations, interpretations and decisions. These cognitive images do not need to be representative of the reality, since beliefs reflecting the attributes are based on personal views, and not on objective truth, and are therefore, subjective (Neal et al., 1999).

Affective image components are defined as emotional reactions (e.g. Walmsley and Young, 1998), responses (e.g. Pocock and Hudson, 1978) and feelings (e.g. Russel, 1980) towards destinations, therefore, the more appealing the cognitive image of the place, the better the affective evaluation is (Sahin and Baloglu, 2011). Even though in everyday life people do not usually resolve image into cognitive and affective components unless they are asked to do so (Baloglu and Brinberg, 1997), decomposition of image into cognitive and affective parts, from a theoretical point of view, gives a better understanding of its structure and elements (Baloglu and Love, 2005) and provides an opportunity for in-depth analyses (Bagozzi and Burnkrant, 1985). There seems to be a consensus among tourism researchers that TDI is a subjective interpretation of reality made by the tourists (Bigne et al., 2001) and that both cognitive and affective evaluations are equally important (Beerli and Martin, 2004; Kim and Richardson, 2003; Pezenka and Buchta, 2012). TDI, therefore, should be seen as multi-dimensional comprising of both beliefs and knowledge about the destination's attributes and people's feelings toward it (Martin and Bosque, 2008). Still, in the early 1990s, the literature was overwhelmed with one-dimensional models of TDI mainly focused on its cognitive dimension (measurable tangible physical attributes) only (e.g. Gartner, 1989; Schroeder, 1996). Recently, a considerable amount of destination studies addressed both cognitive and affective image components (e.g. Agapito et al., 2010; Baloglu and Love, 2005; Hosany et al., 2006; Kim and Richardson, 2003; Kim and Perdue , 2011; Pike and Mason, 2011; Pike and Ryan, 2004; Martin and Bosque, 2008; Pezenka and Buchta, 2012; Sonmez and Sirakaya, 2002; Wang and Hsu 2010) as a reaction towards Baloglu and Brinberg's (1997) criticism that studying only the cognitive dimension might lead to erroneous and inconsistent results since "the meaning of a place is not entirely determined by its physical properties" (Ward and Russell, 1981:123). Another stream of authors (e.g. Agapito et al., 2013; Chen and Phou, 2013; Gartner, 1993; Pike and Ryan, 2004; Tasci et al., 2007) supports a layered sequence in the image formation, where cognitive image appears first, followed by its evaluative dimension and cognition, which represents the "decision stage" of image formation or the conative image element and depends on the cognitive and affective stages (Gartner, 1993; Qu et al., 2011; Urbonavicius et al., 2011).

Echtner and Ritchie (1991) showed the conceptualization of $\mathrm{DI}$ from a different angle and suggested that TDI consists of three continuums - attribute-holistic, functionalpsychological and unique features, such as iconic events, feelings or auras and recently their conceptual framework has been adopted by Banyai and Potwarka (2012), Hughes (2008), Stepchenkova and Morrison (2008); Stepchenkova and Li, 2012; Lin et al., (2012). Notwithstanding some recent efforts made to understand the complex structure of TDI (e.g. Martin and Bosque, 2008; Tasci et al., 2007, Lai and Li, 2012), there is still no unified concept of TDI and this could be perceived as another impediment for better understanding of its formation.

So far this paper has focused on the various ways of defining and conceptualizing TDU. The following section discusses the formation of TDI as it is one of the least investigated 
aspects of TDI (Beerli and Martin, 2004) and understanding this complex process still remains a challenge (Pike and Page, 2014), which leads to disagreements among tourism researchers and calls for a conceptual clarification.

\section{Models of Destination Image Formation} TDI formation is generally described as a process through which construction of a mental picture of a place occurs as a reaction towards a flood of formal and informal information (called also stimulus factors) disseminated by various information agents and chosen by the tourists (e.g. Frias et al., 2008; Gartner, 1993; Gunn, 1972; Li et al., 2009). The formation process is also likely to be influenced by tourists' characteristics (e.g. Crompton, 1979; Baloglu and McCleary, 1999). Table 2 below shows various models of TDI formation and TDI elements, determinants and stages their authors have focused on.

Gunn (1972) proposed a two-staged model consisting of organic and induced images, which was later expanded into a seven-stage model of TDI formation based on the variety of information sources individuals get confronted with. This model postulates that different types of information sources affect TDI differently organic images are formed by non-commercial information sources; induced images are based on promotional information and personal experience of the destination modifies the induced images.

Another, analogous model of image formation was developed by Selby and Morgan wherein images "are constructed by the amount, source and objectivity of the available information" (Selby and Morgan, 1996:288). These images are "organic" (derived from non-tourist information sources), "projected" (disseminated by official tourist organizations) and "reevaluated" (taken from actual experience). Similarly, Gartner (1993) suggests a continuum of eight individual information agents based on the level of control exercised by destination marketers, the desired level of market penetration and the perceived credibility by travellers, that independently or in collaboration with each other create a unique individual image.

Table 2. Models of TDI Formation

\begin{tabular}{|c|c|c|c|c|c|c|c|c|c|c|c|c|c|c|c|c|c|}
\hline \multirow[t]{2}{*}{ Author(s) } & \multirow[t]{2}{*}{ Year } & \multicolumn{4}{|c|}{$\begin{array}{l}\text { Structure of } \\
\text { destination image }\end{array}$} & \multicolumn{6}{|c|}{$\begin{array}{l}\text { Factors influencing } \\
\text { destination image } \\
\text { formation }\end{array}$} & \multicolumn{3}{|c|}{$\begin{array}{l}\text { Phases of } \\
\text { destination } \\
\text { image } \\
\text { formation }\end{array}$} & \multicolumn{3}{|c|}{$\begin{array}{l}\text { Types of } \\
\text { destination } \\
\text { image }\end{array}$} \\
\hline & & 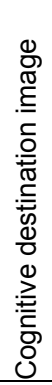 & 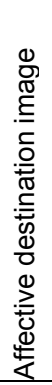 & 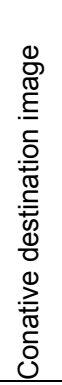 & 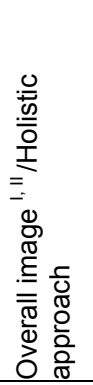 & 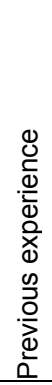 & 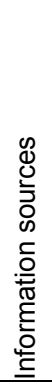 & 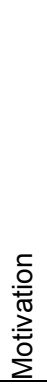 & 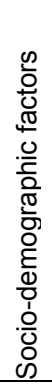 & 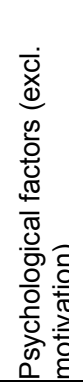 & 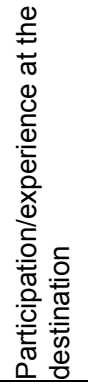 & 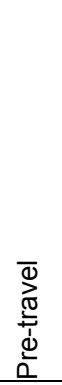 & 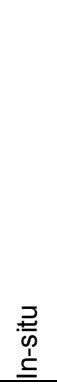 & 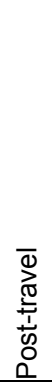 & 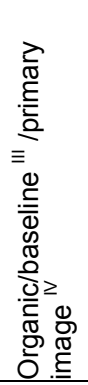 & 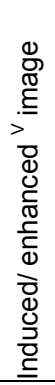 & 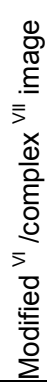 \\
\hline Gunn & 1972 & & & & $x$ & & $x$ & & & & $x$ & $x$ & $x$ & $x$ & $x$ & $x$ & $x$ \\
\hline Stabler & 1988 & & & & $x$ & $x$ & $x$ & $x$ & $x$ & $x$ & & & & & & & \\
\hline Gartner & 1989 & & & $x$ & $x$ & $x$ & $x$ & & & & & & & & & & \\
\hline Chon & 1990 & & & & $x$ & $x$ & $x$ & & & & & $x$ & $x$ & $x$ & $x$ & & $x$ \\
\hline Shelby \& Morgan & 1996 & & & & $x$ & & $x$ & $x$ & & & & $x$ & $x$ & & $x$ & $x$ & $x$ \\
\hline $\begin{array}{l}\text { Baloglu \& } \\
\text { McCleary }\end{array}$ & 1997 & $x$ & $x$ & & $x$ & $x$ & $x$ & $x$ & $x$ & $x$ & & $x$ & & & & & \\
\hline Beerli \& Martin & 2004 & $x$ & $x$ & & $x$ & $x$ & $x$ & $x$ & $x$ & & $x$ & & & $x$ & & & \\
\hline Tasci \& Gartner & 2007 & $x$ & $x$ & & $x$ & $x$ & $x$ & $x$ & $x$ & $x$ & $x$ & $x$ & $x$ & $x$ & $x$ & $x$ & \\
\hline Li et al., & 2009 & & & & & & $x$ & & & & & & & & $x$ & $x$ & \\
\hline Stylidis et al. & 2010 & & & & & $x$ & $\mathrm{x}$ & $x$ & $x$ & $x$ & $x$ & $x$ & & $x$ & & & \\
\hline
\end{tabular}


The above models propose that travellers rely on two main streams of information - nontourist information and commercial information. One major criticism of these models is that travellers are less likely to rely only on one of those streams while searching for information and cannot make a clear distinction between the two. Consequently, the differences and borders between organic and induced images, in the sense used by Gunn (1972), Gartner (1993) and Selby and Morgan (1996) are becoming more and more blurred and elusive (Li et al., 2009), or as Tasci and Gartner (2007: 414) emphasize "mutual exclusivity of organic, induced and autonomous agents are practically non-existent". To address this concern, Li et al. (2009) proposed another two-dimensional representation of the TDI formation process that consists of baseline image based on an inert information search and enhanced image formed by intentional and active information collection. The model, still in its infant stage, was empirically tested with a sample of inadequate size and characteristics (30 students) and despite some robust results, could hardly lead to any generalizations.

Despite the fact that the dynamic nature of the formation process is recognized and acknowledged in these models, they fail to acknowledge the composite elements of TDI and to consider that even though organic and induced images are constructed from general information about a place, "these images are always highly personal" (Gunn, 1988: 23), thus adducing that other, more personal and travellers' related determinants exist.

Fakeye and Crompton's work (1991) refined Gunn's model (1972) by introducing motivation as a determinant and proposed that individuals develop organic images from non-tourism information sources, but with the desire to travel and through active information search the development of induced images takes place. Another model of TDI formation that takes into consideration the linkages between TDI, traveler's decision making process, traveller's satisfaction/dissatisfaction with the destination and the process of comparison between performance expectancy and performance outcome is developed by Chon (1990). One major criticism of his work, however, is that it fails to explicitly specify whether any other TDI exists prior to the formation of the primary image (and how it was formed), which should be the case since people start receiving messages from an early age (Boulding, 1956). As for the models described above, Chon's model does not take into consideration the importance of sociodemographic characteristics of travellers and their impact upon the process of TDI formation and the composite elements of TDI.

Baloglu and McCleary (1997) filled the void left by the above models by proposing a model of image formation before the actual destination experience takes place, which draws a distinction between stimulus factors (quantity and type of information sources) and personal factors (travellers' socio-demographic and psychological characteristics). Nevertheless, this model explains the TDI formation prior to departure only and fails to provide an explanation as to how the image is modified once travellers visit the destination.

Beerli and Martin (2004) while building upon Baloglu and McCleary's concept (1999) described above, developed and empirically confirmed a model, which explains the degree to which a set of factors (primary and secondary information sources, motivation, level of experience with the destination and socio-demographic characteristics) affects the formation of destination's post-image only. Stylidis et al., (2010), on the contrary, overcame this shortcoming by proposing a model of islands image formation consisting of "pre image" (formed through information sources, self-image, socio-psychological factors, motivation, demographic characteristics, personal experience and the destination's marketing).and "post visit" (output of the actual visitation, the intensity of the visit, the psychological condition and the gap between visitation and expectation) stages and destinations' unique characteristics. This model, however, lacks any empirical evidence, emphasizes only on the cognitive image domain and fails to address how its compound parts are affected during pre and post-visit stages by information sources, sociopsychological and demographic factors, travel motivations, etc. More specifically, destination's 
image during the actual experience is overlooked in this conceptual framework.

Recently, a new model of destination was constructed by Tasci and Gartner (2007) which encompasses TDI and consumer behaviour, where TDI is presented as a complex construct consisting of different types of information sources, supply side (the destination itself) and demand side (visitor's socio-demographic and psychological characteristics). These factors are grouped into controllable (marketing, strategy, positioning, promotion), semicontrollable (the image capital - historical, social, physical etc. characteristics of the destination) and uncontrollable (the perceiver's characteristics) inputs based on the degree of control exercised by the destination marketers. The resulting TDI is then linked to the effects it has on pre-, during-, and post-trip consumer behaviour. Again, as observed in the models evaluated above, this model sees TDI holistically and does not explain how TDI determinants could possibly influence affective and cognitive TDI components throughout the different stages of its formation process. Nevertheless, Tasci and Gartner's (2007) proposition of an interlink between the threestaged consumer behaviour and TDI puts forward the notion of a three-staged TDI formation process that reflects the differences in consumer behaviour at different stages. The models discussed above influence the formation of a conceptual framework of TDI proposed later in the paper incorporating the different stages of its formation and multidimensional nature. A summary of the main TDI determinants which have been depicted in the models discussed above or unveiled in previous empirical studies is provided in the next section.

External or stimulus determinants of destination image

\section{Previous Visitation}

Since Gunn's (1972) proposition that there are differences between the image of a destination held by its potential visitors, repeat visitors and non-visitors, a substantial number of researchers and practitioners explored the effect of previous destination experience or lack of experience on TDI (e.g. Baloglu and McCleary 1999; Beerli and Martin, 2004; Cherifi et al, 2014; Choi et al., 2011; Dann 1996; Giraldi, and Cesareo, 2014; Molina et al., 2012; Prebensen, 2007; Tasci and Gartner, 2007; MacKay and McVetty 2002; Sahin and Baloglu, 2011).

Apart from some minor inconsistencies Gunn's idea received sufficient empirical support to infer that destination experience results in more realistic image of it and returned visitors tend to have more realistic, complex and differentiated images (e.g. Dann 1996; Fakeye and Crompton 1991;; Hung et al., 2012; Phelps 1986). Previous visitation was also found be in a positive correlation not only with TDI, but also with the likelihood to revisit the destination (Milman and Pizam, 1995).

Previous experience should also be examined in terms of previous visits to other, similar destinations within the same country as they might give some "pre-taste" of the destination and form perceptions that are different from those of tourists with no previous experience with the country as proved by Mayo and Jarvis (1981) and Gartner (1996). Still, there are insufficient up-to-date studies that focus on this generalization effect in the context of the tourism industry.

\section{Information sources}

The intangible and experiential nature of tourism products is widely recognized in the literature. It engages consumers in an ongoing information search and synthesis, which is recognized by various models of the travel decision making process (e.g. Gartner, 1993; Fakeye and Crompton, 1991; Woodside and Lysonsky, 1989). It is acknowledged that diverse information agents change TDI differently (e.g. Gartner, 1993; Govers et al., 2007; Hung et al., 2012; Prebensen, 2007).

Preliminary work on information sources was undertaken by Gartner (1992), where the subsets were labelled as Overt Induced I and II, Covert Induced I and II, Autonomous agents, Unsolicited organic and Solicited organic agents and Organic agents based on the level of control by destinations marketers, penetration power and perceived credibility. Besides, information sources different from tourism promotion were found to be much more 
important in the formation of a TDI (e.g. Baloglu and McCleary, 1999; Camprubí et al., 2013; Cherifi et al., 2014; Govers et al., 2007; Hanlan and Kelly, 2005, Suarez, 2011). The advent of the Internet has significantly transformed the way people plan and organise travel activities (Buhalis and Law, 2008; Xiang and Gretzel, 2010). In addition, the Internet with its numerous ways (e.g. travel websites, blogs and social media platforms which could be related to autonomous information sources) to connect the tourism industry with the general public and travellers with fellow travellers became another central information source that contributes to the development of a TDI (e.g. Choi et al., 2007; Guttentag, 2010; Hyun and O'Keefe, 2012; Li et al., 2009, Llodra-Riera et al., 2015; Steen Jacobsen and Munar, 2012; Tseng et al., 2015; Jeong et al., 2012; Xiang and Gretzel, 2010). Travellers use social media platforms to visualise, describe and re-call their experience (e.g. Pudliner, 2007; Tussyadiah and Fesenmaier, 2009. Hung et al., 2012) and consciously or subconsciously affect the behaviour of fellow travellers as people have the tendency to rely and trust information coming from third parties (e.g. Mack et al., 2008; Pan et al., 2007). Besides, Lee et al., (2008) and Beeton (2005) suggest that celebrity involvement in destinations' promotional activities stimulate travel flows and positively affect destinations image. A few studies have also revealed that reality shows (e.g. Tessitore et al., 2014) and movies (e.g. Hudson et al., 2011; Kim and Richardson, 2003, Hung et al., 2012, Josiam et al., 2014) can positively modify the image of a place in which the shows or the movies are set. The potential positive impact of travel brochures and postcards on the process of TDI formation has already been highlighted by a small number of studies discussing the link between pictures included in travel brochures, postcards and TDI (e.g. Molina and Esteban, 2006; Milman, 2011; Nicoletta and Servidio, 2012). Both previous destination experience and information sources (sometimes called level of knowledge) are frequently used to describe visitors' level of familiarity with the destination, which is found to be a positive determinant of TDI (e.g. Baloglu, 2001; Kim and Richardson, 2003; Prentice, 2004; Ryan and Cave, 2005, Sun et al., 2013).
However, as the majority of these studies defined TDI holistically without considering its composite structure, the level of influence different information sources have over its cognitive and affective elements was not taken into consideration. This limitation was overcome by several other studies, however, with some contradictory results. Kim and Park's study (2001), for example, reported that information sources are in a direct relationship with both cognitive and affective images. To the contrary, Beerli and Martin (2004) found that advice from friends or relatives is related mainly with the affective domain, whereas autonomous agents mainly influence general and touristic infrastructures (cognitive image domain). In addition, Beerli and Martin (2004) confirmed that induced, organic and autonomous information sources exert a significant level of influence over destinations cognitive image components, but analysed only the effect of previous experience (organic source) over the affective TDI domain. In sharp contrast with the above findings, are the results of Li et al.'s (2008) study on the TDI formation of China. It was empirically proved that only the affective domain of China's image was modified after respondents gathered online information about China as a tourist destination. Still, Boo and Busser's research (2005) refute empirically the above discussed outcomes and conclude that information sources are neither in a relationship with the cognitive nor with the affective components.

This inconsistency among existing studies calls for a research which should incorporate all information sources identified in the literature and the degree of power they exert in the process of shaping destinations' cognitive and evaluative image dimensions in individuals' minds.

\section{Personal determinants of destination image Motivations}

Motivation is considered to be a vital factor in models illustrating the process of TDI formation (Um and Crompton 1990), because as Baloglu and McCleary (1999) note, TDI is related to the benefits sought and to the travellers motivations, which in turn influence TDI (e.g. Buckley, 2012; Grimm and Needham, 2012; Hung et al., 2012; Martin and Bosque, 2008; 
Nicoletta and Servidio 2012; Tang, 2014). There is a notion in the literature that motivations have a direct effect over affective image components (e.g. Beerli and Martin, 2004; Dann, 1996; Gartner, 1993; Walmsley and Jenkins, 1993; Martin and Bosque, 2008). If destinations' cognitive attributes affect their evaluative domain, then motivations and cognitive image elements should also be considered to be indirectly linked. This issue represents a significant lacuna in the literature and requires further clarification.

\section{Socio-demographic characteristics}

Not only previous experience and information sources, but also visitors' socio-demographic characteristics are believed to take part in the process of TDI formation because "no two people see a destination in exactly the same way" (Mayo and Jarvis (1981:42). Various studies have explored the influence of age (e.g. MacKay and Fesenmaier, 1997; Walmsley and Jenkins, 1993; Beerli and Martin; 2004), gender (e.g. Walmsley and Jenkins, 1993; MacKay and Fesenmaier, 1997; Chen and Kerstetter, 1999), household status (e.g. Chen and Kerstetter, 1999), education (Chen and Kerstetter, 1999; Rittichainuwat et. al., 2001), income (e.g. MacKay and Fesenmaier, 1997), geographic distance or country of origin (e.g. Beerli and Martin; 2004; Chen and Kerstetter, 1999; Prebensen, 2007; Rittichainuwat et al., 2001; Sahin and Baloglu, 2011), marital status (e.g. Rittichainuwat et al., 2001) and culture (e.g. Frias et al., 2012) on TDI, but to some inconclusive results due to different samples, destinations and research approaches. Moreover, the role of socio-demographic characteristics as a determining factor on TDI is analysed only on its pre-visit stage, whereas the impact they might have on the way people perceive destinations once they actually experience them has not yet been addressed.

\section{Trip characteristics}

Recently, little research has been done to assess the impact of trip characteristics on TDI. (1984), for instance, suggested that there may be a link between TDI and trip features such as length of stay. Baloglu, in the late nineties (1997), showed that there are variations in the USA image as a destination caused by trip characteristics. The trip variables used in his study include the season of the trip, the party size and the trip companion. Another triprelated variable studied by TDI researchers is the length of stay. Fakeye and Crompton (1991) concluded that long-stayers have better TDI than short-stayers as they found significant differences in terms of TDI between longstayers (over 8 weeks) and short-stayers.

Another issue that requires further discussions and research relates to the potential influence of travel context on travellers' beliefs about a destination (Gertner, 2010; Snepenger and Milner, 1990) as it has been suggested that travellers might change their preferences for specific destination attributes depending on the travel context (Pike and Page, 2014).

Level of engagement with the destination

The relationship between the level of engagement at a destination and TDI is another area that has not attracted sufficient attention yet. Despite the limited available literature, however, it is conceivable that the level of engagement with a destination or the intensity of the experience can affect TDI. Ashworth (1989) argues that there is a relationship between TDI and activities travellers hope to engage in at the destination. Also the findings of Fakeye and Crompton (1991) indicate the existence of such a relationship - the longer the tourists stay, the more things they do and the more differentiated images they have. A more recent study by lordanova (2014) proved that the more active visitors are at the destination in terms of visited sights and attractions and attended events the better the cognitive and the affective image of the place.

The link between TDI and people's behavioural intentions in terms of re-visiting or recommending a destination is highlighted in the next section regardless of the scarce research on this topic.

Tourism destination image as an antecedent of post-visit behaviours

For the well-saturated tourism market, visitors' loyalty is an essential issue (Assaker et al., 2011) - loyal holidaymakers provide stable profit at reduced marketing costs (Korte, 1995) and are also considered to be destinations' 
ambassadors (Oppermann, 2000). Therefore, it is crucial to understand the correlation between TDI and visitors behavioural intentions. Several researchers have suggested that behavioural intentions are suitable indicators of place loyalty measurement and empirically examined the relationship between TDI and people's intention to recommend or revisit particular destinations (e.g. Alcaniz et al., 2009; Assaker et al., 2011; Bigne et al., 2001; Chang et al., 2015; Choi et al., 2011; Greaves and Skinner (2010), Prayag and Ryan, 2012; Molina et al., 2012; Sun et al., 2013; Zhang et al., 2014).

The majority of the existing studies in this area perceives TDI as a one-dimensional construct (overall image) and have not thoroughly studied the relationship between behavioural intentions and destination's cognitive and affective image domains.

Having discussed various models of TDI formation and TDI determinants, the final section of this paper presents a conceptual framework of TDI which explicitly displays the multi-staged process of TDI formation and a set of image determinants based on previous empirical TDI research or included in other models of TDI formation, and also highlights under-researched areas that still require researchers' attention.

\section{A conceptual framework of tourism destination image formation}

The foregoing critical review clearly demonstrates the complex, multidimensional, dynamic and multidisciplinary structure of TDI. It has been observed that despite the wide spectrum of theoretical research and empirically supported studies, there is still no generally accepted definition and conceptual framework of TDI formation, even though many researchers have attempted to develop a better understanding of this multifaceted phenomenon. The critical discussion of the literature also illustrates that research findings on TDI determinants are often competitive and the similarities between them are exceptional. This leads to the lack of a generally accepted conceptual framework that incorporates the whole set of image determinants and their impact on the process of TDI formation. Furthermore, the fragmented character of the existing literature is a consequence of the different stages of TDI formation at which the studies of image determinants were conducted. For example, while some studies deal with TDI before actual visitation, others examine the post-trip travellers' behaviour and the degree of loyalty developed towards the visited destination. This shows the need of dividing the formation process into different stages (a priori, in situ and a posteriori) where a series of image determinants influence the cognitive and affective components at each level, but in a different way and with a different strength. TDI "a priori" could be seen as individual's mental representation of the place with or without having physically experienced it. The "in situ" TDI is shaped during the time of the actual destination experience and the "posteriori" image is the image, which stays with the individual once the experience is over and influences their post-trip intentions (revisit and recommendation) as in Tasci and Gartner's model (2007). Besides, even if a determinant might be dominant at one particular point (e.g. information sources at "a priori" level), its dominance might increase with the emergence of another determinant (e.g. motivation) or retreat with a move onto the next stage ("onsitu" image). This changeable nature of image determinants is not addressed in the existing body of literature. Also, there are sufficient studies, the majority of them contradictory though, discussing the "a priori" and "posteriori" TDI, while the middle stage, or the "in situ" TDI and its determinants is still lacking rigorous analysis and understanding. This paper, therefore, endeavours to provide a conceptual clarity of destination image formation and to propose a conceptual framework of destination image formation and development which is visualized in Figure 2 below.

The framework presents TDI as consisting of both cognitive and affective elements and allies with Bagozzi and Burnkrant (1985) and Baloglu and Love (2005) who argue that from a theoretical point of view, the decomposition of image into cognitive and affective parts gives better understanding of its structure. This operationalization of TDI also supports consecutive analyses, even though people in their everyday lives do not split the image of an object into cognitive and affective parts, unless 
they are asked to do so (Baloglu and Brinberg, 1997). In this framework, therefore, people's knowledge/beliefs and awareness of a destination illustrate its cognitive image dimension, whereas feelings/emotions towards it reflect its affective image domain.

The proposed conceptual framework contributes to the field of study by 1) explicitly showing the dynamic nature of TDI, 2) identifying the set of factors affecting the different stages of TDI formation and 3) displaying the under-researched areas in the process of TDI formation to support further research. The proposed framework highlights the importance of "time" in the process of TDI formation by featuring its multi-stage character. This dynamic element of TDI formation, even though well recognized in Gunn (1972). Fakeye and Crompton (1991), Selby and Morgan (1996) models, embraced in a few more recent studies (e.g. Campo-Martınez et al., 2010; Choi et al., 2007; Kim and Richardson, 2003; Kim and Morrison, 2005; Yüksel and Akgül, 2007) and further linked with consumers "pre-visit", "during visit", and "post visit" stages in Tasci and Gartner's model (2007), still represents a grey area, which has potential for further studies. Recognizing and analysing the dynamic nature of TDI formation is a significant prerequisite for the development of a better understanding of TDI from both theoretical and practical standpoints. Moreover, despite the numerous studies and models on TDI formation, their main focus is on analysing the "pre-travel" phase of TDI formation and the relationship between the post-travel image travellers' behavioural intentions. Nonetheless, one could argue that the formation of a TDI does not discontinue once travellers' begin their actual experience, but rather goes through a "modification" (Gunn, 1972) or "on-site" stage, which in turn, affects the post-travel evaluation and image, and subsequently the intentions to recommend or re-visit the place.

This framework, therefore, suggests that better understanding of the second stage of DTI is needed, since image determinants forming the "a priori" image of a place, might penetrate its "in situ image and significantly affect it as well. The second stage could be of a crucial importance for further destination visits or recommendations, which indicates that further research on it is vital to support destination marketers who are trying to increase visitors' loyalty.

A set of variables or image determinants elicited from the existing literature on TD formation is also part of the proposed framework as a prerequisite for the formation and development of TDI. Their categorization into personal and stimulus factors is based on Baloglu and McCleary's work (1999). Stimulus factors include previous visitation to the place or similar destinations (e.g. Baloglu and McCleary, 1999; Baloglu and Mangaloglu, 2000; Beerli and Martin, 2004; Choi et al., 2011; Dann 1996; Milman and Pizam, 1995; Prebensen, 2007; Tasci and Gartner, 2007; MacKay and McVetty 2002; Sahin and Baloglu, 2011) and information sources (e.g. Beerli and Martin, 2004; Boo and Busser, 2005; Buhalis and Law, 2008; Gartner, 1993; Govers et al., 2007; Hanlan and Kelly, 2005; Kim and Park, 2001; Jeong et al., 2012; Xiang and Gretzel, 2010).

Personal factors, on the other hand, include socio-demographic characteristics, culture (e.g. Beerli and Martin, 2004; Dann 1996; Um and Crompton, 1999; MacKay and Fesenmaier, 2000; Frías et. al., 2011) and motivation (e.g. Baloglu and McCleary 1999; Beerli and Martin, 2004; Martin and Bosque, 2008).

The possible link between duration of stay (Vogt and Andereck, 2003), "on site" activities and destination's cognitive and affective image dimensions is also incorporated in the proposed conceptual framework as "in situ" TDI antecedents along with the possible effect that cognitive and affective TDI domains have over behavioral intentions (degree of loyalty) as previously done by Bigne et al. (2001), Alcaniz et al. (2009), Choi et al. (2011), Sun et al. (2013), Zhang et al. (2014).

The conceptual framework in order to support further studies in the area also endeavours to highlight areas that still represent a significant lacuna in the literature on TDI formation. For example, the impact of personal and stimulus factors and the level of destination engagement on its "in situ" cognitive and affective image 
dimensions is still under-researched and could merit researchers' attention.

Figure 2 below shows the visual representation of the conceptual framework that emerged from the critical evaluation of the existing body of literature on TDI. It illustrates the multi-staged character and complexity of TDI by i) showing the impact socio-demographic and psychological factors and information sources exert over the different stages of its formation and ii) highlighting grey areas in the literature around this phenomenon that require further discussion. The figure, first of all, demonstrates the importance of "time" as an element in the process of TDI formation and presents TDI as a construct that evolves with time and goes through various stages of formation and development and could potentially predetermine visitors' attitudinal or behavioural loyalty. The "a priory" and "on situ" TDI images are portrayed as having both cognitive and affective components. The conceptual framework, consequently, shows the possible impact of personal, stimulus factors, trip characteristics and visitors' engagement with a destination (e.g. "on-site" activities) on destination's both "a priori" and "in situ" cognitive and affective image dimensions and highlights areas that still represent a significant gap in the literature on TDI formation and could support future research in the area of TDI.

The conducted literature review and the emerged conceptual framework indicate that TDI could be defined as:

A construct consisting of impressions, beliefs, ideas, expectations and feelings accumulated towards a place over time gathered from a variety of information sources and shaped through an individual's socio-demographic and psychological characteristics.

Developing of a new definition, despite the significant number of existing ones, is propelled by the fact that none of them took into account the recognized in the literature dynamic, subjective and composite structure of TDI.

Scope for Further Research, Conclusion and Limitations

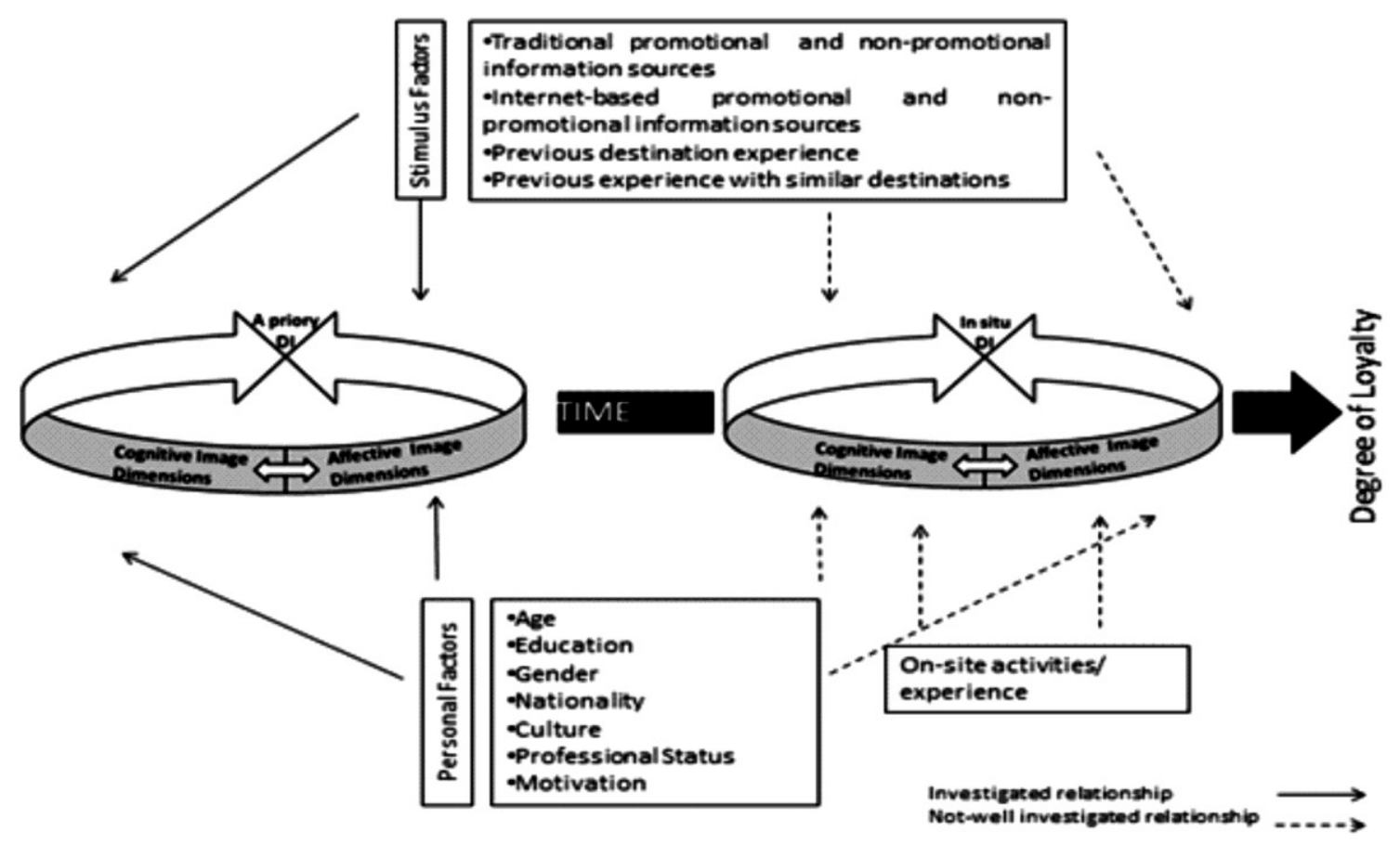

Figure 2. Conceptual framework of destination image formation 
Notwithstanding the variety of studies on TDI, our knowledge as to how to define, conceptualize and operationalize TDI is still rather fragmented and partial due to TDI multiple, relativistic, dynamic and complex character (Gallarza et al., 2012). This paper attempted to provide a conceptual clarity on destination image and its formation process by proposing and visualizing a conceptual framework, which explicitly i) displays the multistaged process of TDI formation, ii) highlights the impact a set of image determinants exert over the different stages of its formation, and iii) shows under-researched areas related to destination image that still require researchers' attention and further discussions. Consequently, this research demonstrated that the complexity of TDI formation process originates from its multi-layered and dynamic nature and is further tangled by a set of image determinants which are always in a state of flux and difficult to pin down. This paper also attempted to collate the fragmented literature on TDI formation and based on the reviewed literature, it identified the most critical antecedents of TDI and developed a set of suggestions for the relationships among the antecedents of TDI and their potential impacts on its formation.

\section{References}

Agapito, D., Valle, P., \& Mendes, J. (2013). The cognitive-affective-conative model of destination image: A confirmatory analysis. Journal of Travel and Tourism Marketing, 30(5), 471-481.

Agapito, D., Mendes, J. C. \& Do Valle, P. O. (2010). Destination image Perspectives of tourists versus residents. European Journal of Tourism, Hospitality and Recreation, 1(1), 90-109.

Ajzen, I. \& Fishbein, M. (1977). Attitudebehaviour relationships: a theoretical analysis and review of empirical research, Psychological Bulletin 84(5), 888-918.

Alcaniz, E., Sanchez, I. \& Blas, S. (2009) The functional-psychological continuum in the cognitive image of a destination: a confirmatory analysis, Tourism Management, 30, 715-23.
Ashworth, G. (1989). Urban tourism: an imbalance in attention. In C. Cooper (ed.), Progress in tourism, recreation and hospitality management, London: Belhaven.33-54

Assaker, G., Vinzi, E., \& O'Connor, P. (2011). Examining the effect of novelty seeking, satisfaction, and destination image on tourists' return pattern: A two factor, non-linear latent growth model. Tourism Management, 32, 890-901.

Bagozzi, P., \& Burnkrant R. (1985). Attitude organization and the attitude-behavior relation: A reply to Dilon and Kumar. Journal of Personality and Social Psychology 49(1), 47-57.

Baloglu, S. (1999) A path analytic model of visitation intention involving information sources, socio-psychological motivations, and Destination image. Journal of Travel and Tourism Marketing, 8 (3), 81-91.

Baloglu, S., \& Brinberg, D. (1997). Affective images of tourism destinations. Journal of Travel Research 35(4), 11-15.

Baloglu, S., \& Love, C. (2005). Association meeting planners' perceptions and intentions for five major US convention cities: the structured and unstructured images. Tourism Management 26(5), 743-752.

Baloglu, S., \& Mangaloglu, M. (2001). Tourism destination images of Turkey, Egypt, Greece, and Italy as perceived by USbased tour operators and travel agents, Tourism Management 22(1), 1-9.

Baloglu, S., \& McCleary, K. (1999) A model of destination image formation. Annals of Tourism Research, 26 (4), 868-897.

Banyai, M., \& Potwarka, L. (2012) Assessing destination images of an Olympic host city using social media. European Journal of Tourism Research 5(1), 618.

Beerli, A., and Martin, J. (2004) Tourists' characteristic and the perceived image of tourist destinations: A quantitative analysis - A case study of Lanzarote, Spain, Tourism Management, 25(5), 623-636.

Beeton, S. (2005). Film-induced tourism. Tonawanda, NW: Channel View Publications. 
Bigne, J., Sanchez, M., \& Sanchez, J. (2001). Tourism image, evaluation variables and after purchase behaviour: Interrelationships. Tourism Management, 22(6), 607-616.

BongoKoo, L., Choong-Ki, L., \& JaeSeok, J. (2014) Dynamic nature of destination image and influence of tourist overall satisfaction on image modification. Journal of Travel Research, 53(2), 239251.

Boulding, K. (1956). The image: knowledge and life in society. Ann Arbor Ml: University of Michigan Press.

Buckley, R. (2012). Rush as a key motivation in skilled adventure tourism: Resolving the risk recreation paradox. Tourism Management, 33, 961-970.

Buhalis, D., \& Law, R. (2008). Progress in tourism management: Twenty years on and 10 years after the internet: The state of eTourism research, Tourism Management, 29(4), 609-623.

Campo-Martínez, S., Garau-Vadell, B., \& Martínez-Ruiz, P. (2010). Factors influencing repeat visits to $a$ destination: the influence of group composition. Tourism Management, 31(6), 862-870.

Camprubí, R., Guia, J., \& Comas, J. (2013). The new role of tourists in destination image formation. Current Issues in Tourism, 16(2), 203-209.

Chang, L., Stylos, N., Yeh, S. \& Tung, Y. (2015). How do motivation, pre-visit information search and destination image affect post-visit behavioural intention? The case of an island destination. European Journal of Tourism Research 9, 8-23.

Chen, P., \& Kerstetter, D. (1999). International students' image of rural Pennsylvania as a travel destination. Journal of Travel Research, 37(3), 256-266.

Chen, C., \& Phou, S. (2013). A closer look at destination: Image, personality, relationship and loyalty. Tourism Management, 36, 269-278.

Cherifi, B., Smith, A., Maitland, R. \& Stevenson, N. (2014). Destination image of non-visitors. Annals of Tourism Research. 49, 190-202.
Choi, J., Kachenko, T., \& Sil, S. (2011). On the destination image of Korea by Russian tourists. Tourism Management 32 , 193-194.

Chi, C., \& Qu, H. (2008). Examining the structural relationships of destination image, tourist satisfaction and destination loyalty: An integrated approach. Tourism Management, 29, 624-636.

Choi, S., Lehto, X. \& Oleary, J. (2007) What does the consumer want from a DMO website? A study of US and Canadian tourists' perspectives. International Journal of Tourism Research. 9(2), 5972.

Chon, K. (1990). The role of destination image in tourism: a review and discussion. The Tourist Review, 45(2), 2-9.

Coshall J. (2000). Measurement of tourists' destination images: The repertory grid approach. Journal of Travel Research 39(1), 85-89.

Crompton, J. (1979). An assessment of the image of Mexico as a vacation destination and the influence of geographical location upon that image. Journal of Travel Research, 17(4), 1823.

Crouch, G. (2011). Destination competitiveness: An analysis of determinant attributes, Journal of Travel Research, 50(1), 27-45.

Dann, G. (1996). Tourist images of a destination: An alternative analysis. In D. R. Fesenmaier, J. T. O'Leary and M. Uysal, (eds.) Recent Advances in Tourism Marketing Research, pp. 4155. New York: The Haworth Press.

Donaldson, R. \& Ferreira, S. (2009). (Re)creating urban destination image: Opinions of foreign visitors to South Africa on safety and security? Urban Forum, 20, 1-18.

Echtner, M., \& Ritchie, J. (1991). The meaning and measurement of destination image. Journal of Tourism Studies, 2(2), 2-12.

Fakeye, P. \& Crompton, J. (1991). Image differences between prospective firsttime, and repeat visitors to the lower Rio Grande Valley. Journal of Travel Research, 30(2), 10-16. 
Frias, D., Rodriguez, M., \& Castaneda, A. (2008). Internet vs. travel agencies on pre-visit destination image formation: An information processing view. Tourism Management, 29(1), 163-179.

Frias, D., Rodriguez, M., Castaneda, A., Sabiote, C., \& Buhalis, D. (2012). The formation of a tourist destination's image via information sources: the moderating effect of culture. International Journal of Tourism Research, 14(5), 437-450.

Fridgen, J. (1987). Use of cognitive maps to determine perceived tourism regions. Leisure Sciences, 9(1), 101-117.

Gallarza M., Gil, I., \& Calderon, H. (2002). Destination image: Towards a conceptual framework. Annals of Tourism Research, 29(1), 56-78.

Gartner, W. (1993). Image formation process. Journal of Travel and Tourism Marketing, 2(2/3), 191-215.

Gartner, W. (1989). Tourism image: Attribute measurement of state tourism products using multidimensional scaling techniques. Journal of Travel Research, 28(2), 16-20.

Gertner, R. (2010). Similarities and differences of the effect of country images on tourist and study destinations. Journal of Travel and Tourism Marketing. 27(4), 383-395.

Giraldi, A. \& Cesareo, L. (2014). Destination image differences between first-time and return visitors: an exploratory study on the city of Rome. Tourism and Hospitality Research, 14(4), 197-205.

Gnoth, J., Baloglu, S., Ekinci,Y. \& SirakayaTurk, E. (2007). Introduction: Building destination brands. Tourism Analysis, 12(5/6), 43-55.

Golledge, R. \& Stimson, R. (1987). Analytical behavioural geography. New York: Croom Helm.

Govers, R., Go, F. \& Kumar, K. (2007). Promoting tourism destination image. Journal of Travel Research, 46(1), 1523.

Greaves, N., \& Skinner, H. (2010). The importance of destination image analysis to UK rural tourism. Marketing Intelligence \& Planning, 28(4), 486507.
Grimm, K. \& Needham, M. (2012). Internet promotional material and conservation volunteer tourist motivations: A case study of selecting organizations and projects. Tourism Management Perspectives, 1, 17-27.

Gunn, C. (1972). Vacationscape: Designing Tourist Regions. Austin, Texas: University of Texas.

Guttentag, D. (2010). Virtual reality: Applications and implications for tourism. Tourism Management, 31, 637-651.

Hanlan, J. \& Kelly, S. (2005). Image formation, information sources and an iconic Australian tourist destination. Journal of Vacation Marketing, 11(2), 163-177.

Hosany, S., Ekinci, Y., \& Uysal, M. (2006). Destination image and destination personality: an application of branding theories to tourism places. Journal of Business Research, 59(5), 638-642.

Huang, J. Z., Li, M. \& Cai, L. A. (2010). A model of community-based festival image. International Journal of Hospitality Management, 29, 254-260.

Hudson, S., Wang, Y., \& Gil, S. (2011). The influence of a film on destination image and the desire to travel: a cross-cultural comparison. International Journal of Tourism Research, 13(2), 177-190.

Hughes, H. L. (2008). Visitor and non-visitor destination images: The influence of political instability in South-Eastern Europe. Tourism, 56(1), 59-74.

Hume, D. (2010). A treatise of human nature. Digireads.com. Publishing.

Hung, J., Lin, F., Yang, W. \& Lu,K. (2012). Construct the destination image formation model of Macao: The case of Taiwan Tourists to Macao. Tourism and Hospitality Management, 18(1), 19-35.

Hunt, J. (1975). Image as a factor in tourism development. Journal of Travel Research, 13(3), 1-7.

Hunter, W. (2012). Projected destination image: A visual analysis of Seoul. Tourism Geographies, 14(3), 419-443.

Hyun, M. Y., \& O'Keefe, R. M. (2012). Virtual destination image: testing a telepresence model. Journal of Business Research, 65(1), 29-35. 
Ivanov, S. H., Illum, S. F., \& Liang, Y. (2010). Application of destination brand molecule on destination image and brand perception: An exploratory study. Tourism, 58(4), 339-360.

Iordanova, E. (2014). Exploring the relationship between visitors' level of engagement with a destination and its perceived image: The Case of Linz, Austria; Paper presented at the Global Tourism and Hospitality Conference and Asia Tourism Forum, 18th - 20th May 2014, Hong Kong.

Jenkins, H. (1999). Understanding and measuring tourist destination image. International Journal of Tourism Research, 1(1), 1-15.

Jeong, C., Holland, S., Jun, S. \& Gibson, H. (2012). Enhancing destination image through travel website information. International Journal of Tourism Research, 14(1), 16-27.

Josiam, B. M., Spears, D., Dutta, K., Pookulangara, S. A., \& Kinley, T. L. (2014). Namastey London: Bollywood movies and their impact on how Indians perceive European destinations. Hospitality Review, 31(4) pp. Article 2. 2-22.

Kelman, H. (1965). International behaviour: A social-psychological analysis. New York: Holt, Rinehart and Winston.

Kim, H. \& Richardson, S. (2003). Motion picture impacts on destination images. Annals of Tourism Research, 30(1), 216-237.

Kim, S. \& Morrison, A. (2005). Changes of images of South Korea among foreign tourists after the 2002 FIFA World Cup. Tourism Management, 26(2), 233-247.

Kim, D. \& Perdue, R. (2011). The influence of image on destination attractiveness. Journal of Travel and Tourism Marketing. 28(3), 225-239.

Ko, D. \& Park, S. (2000). Five aspects of tourism Image: A review. International Journal of Tourism Science, 1(1), 7992.

Korte, C. (1995) Kundenzufriedenheit, Planung und Analyse, 6, 36-39.

Kozak, M. \& Baloglu, S. (2011). Managing and marketing tourist destinations: strategies to gain a competitive edge. New York, London: Routledge.
Lai, K. \& Li, Y. (2012). Core-periphery structure of destination image-concept, evidence and implication. Annals of Tourism Research, 39(3), 1359-1379.

Lee, J., \& Back, B. (2008). Attendee-based brand equity. Tourism Management, 29(2), 331-344.

Lee, K., Lee, K., \& Lee, K. (2005). Korea's destination image formed by the 2002 World Cup. Annals of Tourism Research, 32(4), 839-858.

Leisen, B. (2001). Image segmentation: the case of a tourism destination. Journal of Services Marketing, 15(1), 49-66.

Lee, S., Scott, D. \& Kim, H. (2008). Celebrity fan involvement and destination perceptions. Annals of Tourism Research, 35(3), 809-832.

Lin, Y.-H., Chen, C. \& Park, C. W. (2012). The salient and organic images of Taiwan as perceived by mainland Chinese tourists. Asia Pacific Journal of Tourism Research, 17(4), 381-393.

Li, X., Pan, B., Zhang, L. \& Smith, W. (2009). The effect of online information search on image development: Insights from a mixed-methods study. Journal of Travel Research, 48(1), 45-57.

Llodra-Riera, I., Martínez-Ruiz, M. P., JimenezZarco, A., I. \& Izquierdo-Yusta, A. (2015). A multidimensional analysis of the information sources construct and its relevance for destination image formation. Tourism Management. 48, 319-328.

Mack, R., Blose, J., \& Pan, B. (2008). Believe it or not: Credibility of blogs in tourism. Journal of Vacation Marketing, 14(2), 133-144.

MacKay, K., \& Fesenmaier, D. (1997). Pictorial element of destination in image formation. Annals of Tourism Research 24(3), 537-565.

MacKay, K., \& Fesenmaier, D. (2000). An exploration of cross-cultural destination image assessment. Journal of Travel Research, 38(4), 417-423.

MacKay, K. \& McVetty, D. (2002). Images of first-time visitors to Queen Charlotte Islands and Gwaii Haanas National Park Reserve. Journal of Park and Recreation Administration, Special 
Issue: Marketing in Parks, 20(2), 1130.

Martin, H. \& Bosque, I. (2008). Exploring the cognitive-affective nature of destination image and the role of psychological factors in its formation. Tourism Management, 29(2), 263-277.

Mazanec, J., \& Schweiger, G. (1981). Improved marketing efficiency through multiproduct brand names? An empirical investigation of image transfer. European Research, 9, 32-44.

Mazursky, D., \& Jacoby, J. (1986). Exploring the development of store images. Journal of Retailing, 62(2), 145-165.

Milman, A., \& Pizam, A. (1995). The role of awareness and familiarity with a destination: The central Florida case. Journal of Travel Research, 33(3), 2127.

Milman, A. (2011). The symbolic role of postcards in representing a destination image: The case of Alanya, Turkey. International Journal of Hospitality and Tourism Administration, 12, 144-173.

Molina, A. \& Esteban, A. (2006). Tourism brochures: image and usefulness. Annals of Tourism Research, 33(4), 1036-1056.

Molina, R., Frras-Jamilenaa, D., \& CastacedaGarchaа, J. (2013). The moderating role of past experience in the formation of a tourist destination's image and in tourists' behavioural intentions. Current Issues in Tourism, 16(2), 107-127.

Neal, C., Quester, P., \& Hawkin, D. (1999). Consumer behaviour: implications for marketing strategy. McGraw-Hill: Sydney.

Nicoletta, R. \& Servidio, R. (2012). Tourists' opinions and their selection of tourism destination images: An affective and motivational evaluation. Tourism Management Perspectives, 4, 19-27.

Olson, J. \& Maio, G. (2004). Attitudes in social behaviour. In T. Millon and M. J. Lerner (Eds.), Handbook of psychology, Volume 5: Personality and social psychology: New York: John Wiley and Sons. 299-326.

Oppermann, M. (1996). Convention destination image: analysis of association meeting planners' perceptions. Tourism Management, 17(3), 175-182.

Pan, B, Litvin, \& O'Donnell, T. (2007). Understanding accommodation search query formulation: The first step in putting 'heads in beds'. Journal of Vacation Marketing 13(4), 371-381.

Phelps, A. (1986). Holiday - destination image the problem of assessment. Tourism Management, 7(3), 168-180.

Pezenka, I. \& Buchta, C. (2012). Measuring the resemblance between pictorial and verbal city image spaces. International Journal of Culture, Tourism and Hospitality Research, 6(4), 326-339.

Pike,S. \& Mason, R. (2011). Destination competitiveness through the lens of brand positioning: the case of Australia's Sunshine Coast. Current Issues in Tourism. 14(2), 169-182.

Pike, S. \& Page, S. (2014). Destination Marketing Organizations and destination marketing: A narrative analysis of the literature. Tourism Management 41, 202-227.

Pike, S. \& Ryan, C. (2004). Destination positioning analysis through a comparison of cognitive, affective, and conative perceptions. Journal of Travel Research, 42(4), 333-342.

Pocock, D. \& Hudson, R. (1978). Images of the urban environment. Macmillan.

Prayag, G. \& Ryan, C. (2012). Antecedents of tourists' loyalty to Mauritius: The role and influence of destination image, place attachment, personal involvement, and satisfaction. Journal of Travel Research, 51(3), 342-356.

Prebensen, N. (2007). Exploring tourists' images of a distant destination. Tourism Management 28(3), 747-756.

Qu, H., Kim, L. H., \& Im, H. H. (2011). A model of destination branding: Integrating the concepts of the branding and destination image. Tourism Management, 32(3), 465-476.

Ramkissoon, H., Uysal, M. \& Brown, K. (2011). Relationship between destination image and behavioral intentions of tourists to consume cultural attractions. Journal of Hospitality Marketing and Management. 20(5), 575-595. 
Reynolds, W. (1965) The role of the consumer in image building. California Management Review, 7(3), 69-76.

Richards, G., \& Wilson, J. (2004). The impact of cultural events on city image: Rotterdam, cultural capital of Europe 2001. Urban Studies, 41(10), 19311951.

Rittichainuwat, B., Qu, H., \& Brown, T. (2001). Thailand international travel image. Cornell Hotel and Restaurant Administration Quarterly, 47(4), 82-95.

Rodrigues, A., Correia, A. \& Kozak, M. (2011). A multidisciplinary approach on destination image construct. Tourismos: An International Multidisciplinary Journal of Tourism, 6(3), 93-110.

Russell, J. (1980). A circumplex model of affect. Journal of Personality and Social Psychology 39(6), 1161-1178.

Ryan, S. \& Cave, J. (2005). Structuring destination image: A qualitative approach. Journal of Travel Research 44(2), 143-147.

Sahin, S. \& Baloglu, S. (2011). Brand personality and destination image of Istanbul. Anatolia - An International Journal of Tourism and Hospitality Research, 22(1), 69-88.

Schroeder, T. (1996). The relationship of residents' image of their state as a tourist destination and their support for tourism. Journal of Travel Research, 34(4), 471-473.

Selby, M. \& Morgan, N. (1996). Reconstructing place image: A case study of its role in destination market research. Tourism Management, 17(4), 287-294.

Smith, W., Li, X., Pan, B., Witte, M. \& Doherty, S. (2015). Tracking destination image across the trip experience with smartphone technology. Tourism Management, 48, 113-122.

Snepenger, D. \& Milner, L. (1990). Demographic and situational correlates of business travel. Journal of Travel Research, 28(4), 27-32.

Sonmez, S. \& Sirakaya, E. (2002). A distorted destination image? The case of Turkey. Journal of Travel Research 41(2), 185196.
Steen Jacobsen, J. \& Munar, L. (2012). Tourist information search and destination choice in a digital age Tourism Management Perspectives, 1, 39-47.

Stepchenkova, S. \& Eales, J. (2011). Destination image as quantified media messages: The effect of news on tourism demand. Journal of Travel Research, 50(2) 198- 212.

Stepchenkova, S. \& Li, X. (2012). Chinese outbound tourists' destination image of America: Part II. Journal of Travel Research, 51(6), 687-703.

Stepchenkova, S. \& Mills, J. (2010). Destination image: A meta analysis of 2000-2007 research. Journal of Hospitality, Marketing and Management, 19, 575-609.

Stylidis, D., Terzidou, M. \& Terzidis, K. (2010). Destination image formation. In Sakas, D. And Konstantopolous, N. (eds.) Marketing and Management Sciences: Proceedings of the International conference on ICMMS 2008. London: Imperial College Press. 591 - 596.

Suárez, M. J. (2011). The impact of secondary information sources on the formation of the tourist image: The case of rural tourism in Galicia. European Journal of Tourism, Hospitality and Recreation, 2(1), 72-94.

Sun, X., Chi, C., \& Xu, H. (2013). Developing destination loyalty: The case of Hainan Island. Annals of Tourism Research. 43, 547-577.

Urbonavicius, S., Dikcius, V., \& Navickaite, S. (2011). Country image and product evaluations: Impact of a personal contact with a country. Engineering Economics, 22(2), 214-221.

Tang, Y. (2014). Travel motivation, destination image and visitor satisfaction of international tourists after the 2008 Wenchuan earthquake: A structural modelling approach. Asia Pacific Journal of Tourism Research, 19(11), 1260-1277.

Tapachai, N., \& Waryszak, R. (2000). An examination of the role of beneficial image in tourist destination selection. Journal of Travel Research, 39(1), 3744. 
Tasci, A., Gartner, W. \& Cavusgil, S. (2007). Conceptualization and operationalization of destination image. Journal of Hospitality and Tourism Research, 31(2), 194-223.

Teodorescu, N., Pârgaru, I., Stăncioiu, A. F., Matei, E. \& Botos, A. (2014). Modelling the image research of a tourism destination. Amfiteatru Economic, 16 (8), 1076-1088

Tseng, C., Wu, B., Morrison, A., Zhang, J. \& Chen. Y (2015) Travel blogs on China as a destination image formation agent: A qualitative analysis using Leximancer. Tourism Management. 46, 347-358.

Tessitore, T., Pandelaere, M., \& Kerckhove, A. (2014). The amazing race to India: Prominence in reality television affects destination image and travel intentions. Tourism Management 42, 3-12.

Thomas, N. (2009). Entry on visual imagery and consciousness. In Banks, W. P. (ed.) Encyclopaedia of Consciousness, Volume 2. Oxford: Academic Press/Elsevier.

Tussyadiah, I., \& Fesenmaier, D. R. (2009). Mediating tourists experiences-access to places via shared videos. Annals of Tourism Research, 36(1), 24-40.

Um, S., \& Crompton, J. (1990). Attitude determinants in tourism destination choice. Annals of Tourism Research, 17(3), 432-448.

Vogt, C. \& Andereck, K. (2003). Destination perceptions across a vacation. Journal of Travel Research, 41 (4), 348-354.

Walmsley, D. \& Jenkins, J. (1993). Appraisive images of tourist areas: Application of personal constructs. Australian Geographer, 24(2), 1-13.
Walmsley, D. \& Young M. (1998). Evaluative images and tourism: The use of personal constructs to describe the structure of destination images. Journal of Travel Research, 36(3), 65-69.

Wang, C. \& Hsu, M. (2010). The relationships of destination image, satisfaction, and behavioral intentions: An integrated model. Journal of Travel and Tourism Marketing, 27(8), 829-843.

Ward, L., \& Russell, A. (1981). The psychological representation of molar physical environments. Journal of Environmental Psychology, 110(2), 158-162.

Woodside, A., \& Lysonski, S. (1989). A general model of traveller destination choice. Journal of Travel Research, 17(4), 814.

Xiang, Z. \& Gretzel, U. (2010). Role of social media in online travel information search. Tourism Management, 31(2), 179-188.

Yuan, W., Xuegang, F., \& Xiaodong, S. (2014). A model of temporal changes in destination images. Tourism Tribune, 29(10), 20-30.

Yuksel, A. \& Akgil, O. (2007) Postcards as affective image makers: An idle agent in destination marketing. Tourism Management, 28(3), 714-725.

Zhang,H., Fu, X, Cai, A. \& Lu, L. (2014). Destination image and tourist loyalty: A meta-analysis. Tourism Management, 40, 213-223.

Zimbardo, P., \& Richard, G. (1999) Psychology and Life. $15^{\text {th }}$ ed. New York: Longman. 